\title{
Peningkatan Ekonomi Pesantren Melalui Budidaya Vanili Dengan Sistem Agrikultur Di Kabupaten Bondowoso
}

\author{
Mustaqim Makki, H Subairi \\ Sekolah Tinggi Agama Islam Nurul Huda Kapongan Situbondo \\ mustaqimmakky@gmail.com
}

\begin{abstract}
Religious Education Boarding Schools in Indonesia whose numbers Achieve money actually have significant money in the field of money. But the potential possessed by pesantren has not been much considered, either by the government or by the internal pesantren itself. The government so far has not been optimal in seeing the economic potential of the pesantren. Because pesantren consider traditional educational institutions that do not have strategic value in the economic field. While the majority of pesantren are considering economic matters related to pesantren, because they are related to the world economy, this should not be taken seriously. Perspectives from experts on pesantren say that pesantren are still engaged in traditional education which still maintains learning of classical books. Meanwhile, if we look at the potential and development of pesantren, as stated by Azzumardi Azra, pesantren should now be expected to no longer play its traditional functions, namely: Transition and transfer of religious knowledge (Islam), maintenance of Islamic traditions, Ulama makers, can also visit health care facilities, the center for the development of appropriate technology for rural communities, a center for efforts to save preservation and the environment is even more important to be a center for community empowerment and its surroundings. With this pesantren economic empowerment concept and seeing opportunities for Vanilla plants (green gold), pesantren will be easier to overcome pesantren economic difficulties for educational operations.
\end{abstract}

\section{Keywords: Pesantren Economy, Vanilla Cultivation, Agriculture System}

\section{A. Pendahuluan}

Vanili adalah tanaman rempah penyegar penghasil bubuk vanili yang umumnya digunakan sebagai pengharum makanan dan minuman. Selain itu belakangan ini vanili juga digunakan untuk penyedap rasa dan juga di dunia medis. Bubuk vanili tersebut dihasilkan dari buahnya yang berbentuk polong dan butuh pengolahan tersendiri agar bisa menghasilkan harumnya. Vanili sendiri pertama kali ditemukan oleh orang Indian di Mexico pada tahun 1570an.

Tanaman vanili memiliki nilai ekonomi yang sangat tinggi dimana harganya dalam $1 \mathrm{Kg}$-nya bisa menembus harga hingga 3,5 juta rupiah bahkan lebih lagi. Membudidayakan tanaman vanili ini begitu menggiurkan, mengingat siklus hidup 
yang panjang dan, alam Indonesia sangat cocok serta mendukung dan produktivitas tanamannya bisa terus-menerus menghasilkan.

Meskipun memiliki harga jual yang tinggi, namun tak berarti semua petani bisa sukses dengan mudah. Banyak petani yang mengalami kegagalan dalam membudidayakan tanaman ini. Kebanyakan kegagalan terjadi karena kurangnya pengetahuan, kurangnya ketekunan dan juga masih kurangnya kesadaran petani dalam menjaga mutu. Selain hal tersebut di atas, ada juga faktor-faktor eksternal yang mempengaruhi keengganan petani dalam membudidayakan vanili, diantaranya jalur tata niaga yang belum tertata, belum terjamin keamanan kebunnya, belum bersatu petani-petani vanili dalam menjaga mutu serta nilai komoditas dan yang terutama adalah vanili belum mendapatkan perhatian yang serius dari pemerintah. Jadi ada banyak faktor yang mempengaruhi dan menentukan keberhasilan pengembangan perkebunan vanili di Indonesia.

Butuh peran serta semua pihak, dimana petani tak akan bisa berdiri sendiri tanpa dukungan pemerintah dalam kebijakan serta keberpihakan kepada petani vanili. Pemerintah juga tak akan bisa bergerak sendiri tanpa melibatkan petani-petani yang secara tradisional sudah membudidayakan vanili. Petani dan Pemerintah butuh dukungan lembaga pendidikan serta penelitian, di mana hasil riset-riset tentang vanili bisa diaplikasikan dengan baik. Butuh kolaborasi yang bersinergis dalam membangun dan mengembangkan perkebunan vanili di Indonesia.

Eksistensi Pesantren sejak pra kemerdekaan Indonesia telah banyak memberikan kontribusi pada masyarakat dan juga Bangsa Indonesia. Pesantren menyuguhkan pola didik yang berbeda dengan pendidikan konvensional. Konstruk yang diciptakan pada lingkungan pesantren memprioritaskan nilai-nilai Attitude (Akhlak). Pesantren sebagai lembaga pendidikan keagamaan tradisional di Indonesia yang dalam sejarahnya telah mengakar berabad-abad jauh sebelum indonesia merdeka dan jauh sebelum kerajaan Islam berdiri (Warson Munawwir: 1997: 87). Pendapat lain menyebutkan bahwa pesantren mengandung makna ke-Islaman sekaligus keaslian (indigenous) Indonesia (Herman DM: 2013).

Pesantren didirikan untuk memenuhi tuntutan zaman. Sebagaimana Sunnatullah serta keniscayaan sejarah (historical necessity) jaman pun berubah. Dari sini pesantren senantiasa dituntut mampu menyesuaikan diri dengan perubahan, tanpa harus tercerabut dari akar tradisi serta khazanah keagamaannya. Pesantren di Indonesia yang jumlahnya Mencapai ribuan sebenarnya mempunyai potensi yang sangat besar dalam bidang ekonomi. Namun potensi yang dimiliki oleh pesantren belum banyak diperhatikan, baik oleh pemerintah maupun oleh internal pesantren itu sendiri. Pemerintah selama ini jarang melihat potensi ekonomi yang dimiliki oleh pesantren. Karena pesantren dianggap lembaga pendidikan tradisional yang tidak memiliki nilai strategis dalam bidang ekonomi. Sedangkan sebagian besar pesantren menganggap bahwa persoalan ekonomi bukanlah urusan pesantren karena urusan ekonomi merupakan persoalan duniawi, sehingga tidak perlu diperhatikan secara serius. 
Perspektif para pakar tentang pesantren secara mayoritas mengatakan demikian bahwa pesantren masih bergerak dalam bidang pendidikan tradisional yang masih mempertahankan pembelajaran kitab-kitab klasik (Moh Nadzir: 2015). Padahal jika kita melihat potensi dan perkembangan pesantren seperti yang dikemukakan oleh Azzumardi Azra, pesantren sekarang harus diharapkan tidak lagi sekedar memainkan fungsi tradisionalnya (Azzumardi Azra, 1997: 22) yaitu: Tranmissi dan Tranfer ilmuilmu agama (Islam), pemeliharaan tradisi Islam, menciptakan Ulama, tetapi juga menjadi pusat penyuluhan kesehatan, pusat pengembangan tekhnologi tepat guna bagi masyarakat pedesaan, pusat usaha-usaha penyelamatan pelestarian dan lingkungan hidup dan lebih penting lagi menjadi pusat pemberdayaan masyarakat dan sekitarnya.

Pemberdayaan terhadap ekonomi pesantren di Indonesia bukan kali pertama dilakukan termasuk pada penelitian ini. Ada banyak pemberdayaan yang telah dilakukan oleh para peneliti guna mengembangkan khazanah keilmuan dan memberikan formulasi khusus sehingga pesantren tidak hanya berhasil mengembangkan keilmuan Islam akan tetapi juga mengembangkan pada potensi yang dalam hal ini ekonomi pesantren. Seiring dengan berkembangnya pesantren tentu dalam sektor ekonomi pesantren tidak semuanya berjalan dengan baik. Jika pesantrenpesantren besar (jenjang pendidikannya lengkap dan santrinya banyak) dalam manajemen ekonominya tentu mudah, karena perputaran ekonomi sangat masif tidak serumit pada pesantren kecil (pesantren yang jenjang pendidikannya hanya pada sampai Aliyah sederajat atau bahkan tidak ada sekolah formalnya) yang kembang kempis mengelolah dana keuangan disektor perekonomian pesantren. Pesantren besar bisa mengelolah perekonomiannya dari hasil pembayaran uang pesantren dari santri, karena pesantren yang jenjang pendidikannya lengkap dan memiliki santri bisa puluhan ribu orang, dilain sisi juga bisa memaksimalkan sumbangsih dari organisai kealumniannya dan tentu jaringan yang dibangun sudah maksimal sehingga masalah perekonomian pesantren besar tidak lagi menjadi kendala yang sangat serius. Berbeda dengan keberadaan Pesantren kecil yang ada dipelosok pedesaan yang hanya memiliki puluhan hingga ratusan santri, apalagi beberapa pesantren ada yang memberikan pelayanan garatis bagi santri yang taraf perekonomiannya dibawah rata-rata. Jangankan mau mengembangkan sarana dan prasarana, dana bisyaroh (Gaji asatidz dan asatidzah) tenaga pengajarnya saja jauh dibawah UMR (Upah Minimum Regional). Sehingga konstruk yang dibangun adalah mengistilahkan gaji dengan bisyaroh atau barokah agar tenaga pendidik dan pengurusnya memiliki hati yang ikhlas. Sedangkan pada sisi yang lain, tenaga pengajarnya juga memiliki tanggungan keluarga, jika hanya memiliki income keuangan keluarga pada bisyaroh tersebut, maka tidaklah cukup untuk memenuhi kebutuhan sehari-hari keluarganya. Hal ini perlu ada problem solving untuk pemberdayaan ekonomi pesanten. Berikut salah satu data bisyaroh untuk guru di pendidikan salah satu pesantren. 
Terakreditasi Nasional Sinta 4: SK. No.30/E/KPT/2019

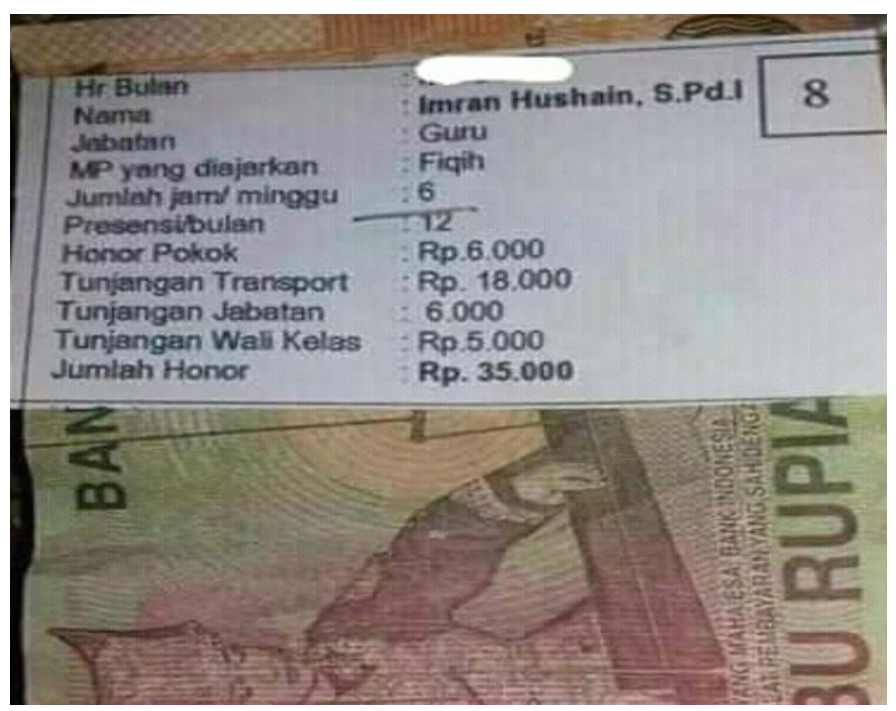

Gambar 1. Bisyaroh Pendidik

Bisa dibayangkan, jika seorang pendidik di lembaga keagamaan, hanya mendapatkan Bisyaroh Rp. 35.000. jangankan buat keperluan sehari-hari, untuk keperluan isi BBM Kendaraan saja hanya cukup tidak lebih dari seminggu. oleh karena itu, perlu kiranya pendidikan dalam hal ini pesantren yang notabene stabilitas ekonomi pesantren masih dibawah rata-rat harus mencari solusi untuk mensejahterakan gurugurunya dan untuk kepentingan Pesantren dalam jangka panjang.

Berdasarkan data di Website PD Pontren Kemenag (Kementrian Agama) Jumlah pesantren per-Tahun 2018 telah mencapai angka 25.938 Pesantren diseluruh Indonesia, dan banyaknya santri yang terdaftar jika dilihat pada pangkalan data Pondok Pesantren Kemenag sejumlah 3.962.700. di wilayah jawa jumlah Pesantren menempati angka yang sangat besar $82.2 \%$. (PD Pontren Kemenag) data ini akan terus berkembang seiring berjalannya waktu sehingga potensi pengembangan ekonomi pesantren sangat signifikan. Hal ini terbukti dengan data grafik yang diambil dari Pangkalan data pondok pesantren bahwa potensi ekonomi pesantren dalam bidang pertanian dan agri bisnis cukup tinggi seperti tampak pada gambar berikut: 


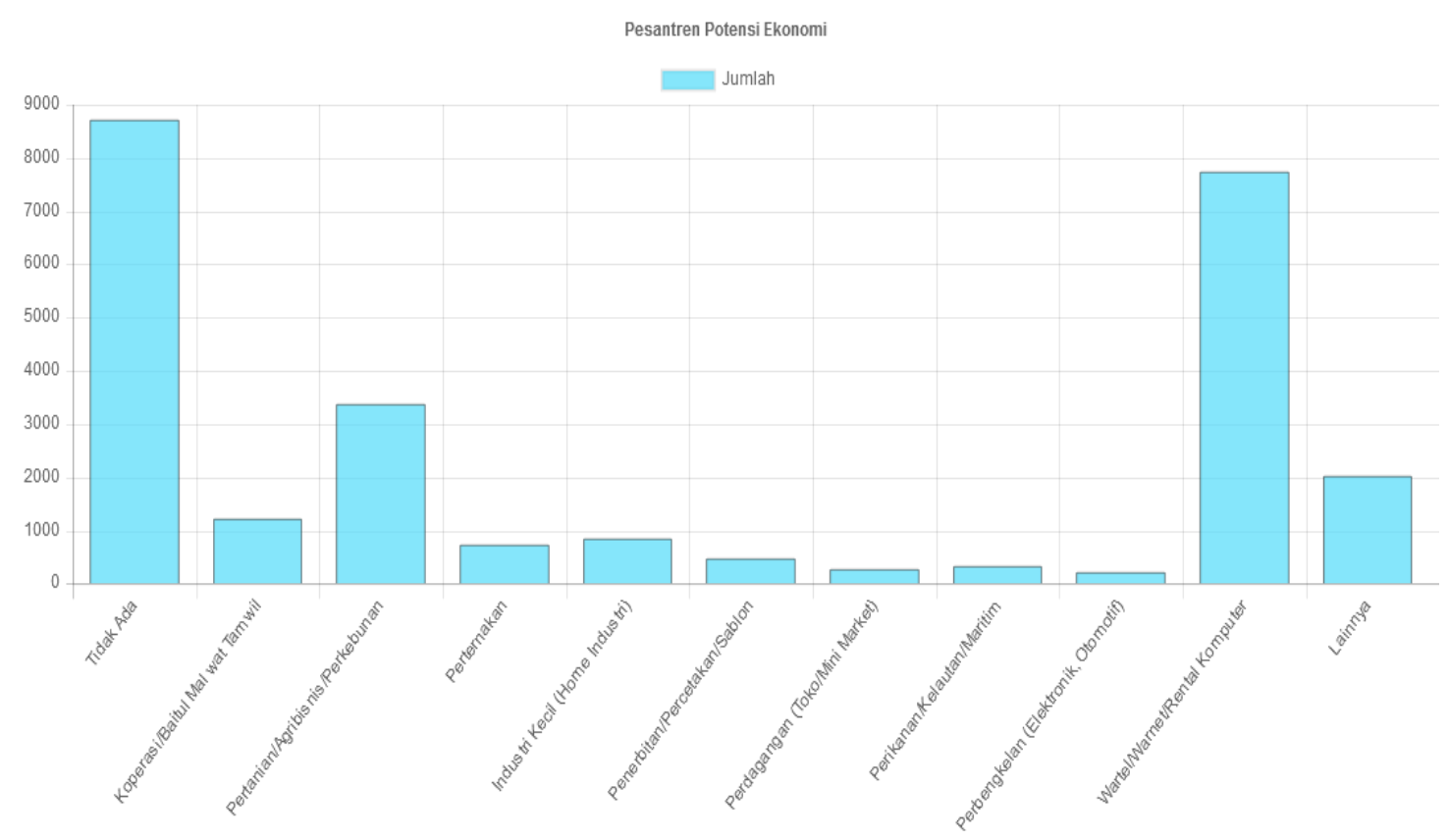

Gambar 2. Potensi Ekonomi Pesantren

Melihat pada grafik di atas, potensi ekonomi pesantren pada pertanian dan agri bisnis sangat tinggi. Jika dimaksimalkan dengan tatakelola dan sistem yang profesional, tidak menutup kemungkinan perekonomian pesantren kecil akan terus berkembang dan tidak lagi berharap pada pihak ketiga. Mengapa harus budidaya vanili untuk pemberdayaan ekonomi pesantren? Hal ini menjadi pertanyaan sangat mendasar dan prinsip. Karena vanili merupakan tumbuhan hutan (liar) yang kaya manfaat dan bernilai jual sangat tinggi. Orang yang paham pada tanaman dan kegunaan vanili menyebutnya dengan emas hujau. Peneliti disini jauh sebelumnya berdiskusi dengan pakar praktikus Vanili, bernama Ir. Rudi Gint yang sekarang menetap di Bondowoso Jawa Timur, sekaligus sebagai Ketua PPVI (Perkumpulan Petani Vanilii Indonesia) Tentang manfaat tumbuhan vanili sebagai alternatif ekonomi pesantren dengan budidaya pada lahan sempit. Penanaman vanili tidak harus ditanam pada lahan yang luas berhektar-hektar, budidaya vanili bisa memanfaatkan lahan yang kurang produktif di setiap sisi halaman atau samping pesantren. Perawatannya pun tudak memerlukan waktu dan biaya yang tinggi asal memahami teori tentang tanaman vanili.

Berdasarkan ulasan urgensitas budidaya vanili pada pemberdayaan ekonomi pesantren dengan sistem Agrikultur adalah sebagai berikut:

Pertama: Menjadi alternatif pada perekonomian pesantren yang selalu terkendala dengan finansial dalam berdikari dan pengembangan sarana pondok pesantren.

Kedua: Pesantren mampu mensejahterakan tenaga pendidiknya dengan segala kebutuhannya sehingga tenaga pendidik yang mengabdi di pesantren tidak lagi memikirkan masalah finansial lagi dan tenaga pendidik lebih fokus mengajar dengan ikhlas. 
Ketiga: Pesantren bisa memberikan reward dan beasiswa pada santri kurang mampu untuk melanjutkan ke jenjang yang lebih tinggi.

Adapun perumusan masalah Dari pemaparan tentang permasalahan yang dialami oleh pesantren "kecil" maka, perlu dirumuskan rumusan masalah sebagai berikut:

1. Bagaimana sistem pemberdayaan ekonomi pesantren dalam memanfaatkan budidaya vanili dengan sistem Agrikultur di Bondowoso?

2. Bagaimana pengelolaan dan mekanisme dari pertama kali tanam hingga panen serta pemasaran dari hasil budidaya vanili untuk menstabilkan perekonomian pesantren "kecil" di Bondowoso?

\section{B. Kajian Teori}

\section{Signifikansi Pemberdayan dan sekilas tentang Vanili}

Pemberdayaan perekonomian Pesantren melalui budidaya Vanili dengan pemanfaatan Agrikultur sangat penting dilakukan untuk membantu sistem ekonomi yang stabil dalam pondok pesantren. Karena melihat potensi tanaman vanili dengan nilai jual yang fantastis. Dilansir dari majalah nasional TRUBUS, harga Vanili per kg, mencapai 5 juta. Dipembeli akhir harga vanili kering menembus angka US\$500 per kg. jika dirupiahkan dengan kurs US\$1= Rp 14.250, harga itu setara Rp 7,1 Juta. angka yang sangat fantastis, namun pengepul tanah air paling banter hanya berani membeli seharga Rp, 4,5-juta. Lebih dari itu, ekportir enggan membeli karena tata niaga dari ekportir hingga pembeli akhir masih panjang. Menurut Rudi, selisih harga lokal dengan dunia bisa sampai Rp 2 juta per kg. menurut eksportir vanili di Jakarta, John $\mathrm{S}$ Tumiwa, Vanili indonesia digemari dunia. Syaratnya pemanen dan pengelolahan pasca panen harus sesuai dengan prosedur. Berikut harga vanili menutut grafik pertahunnya.

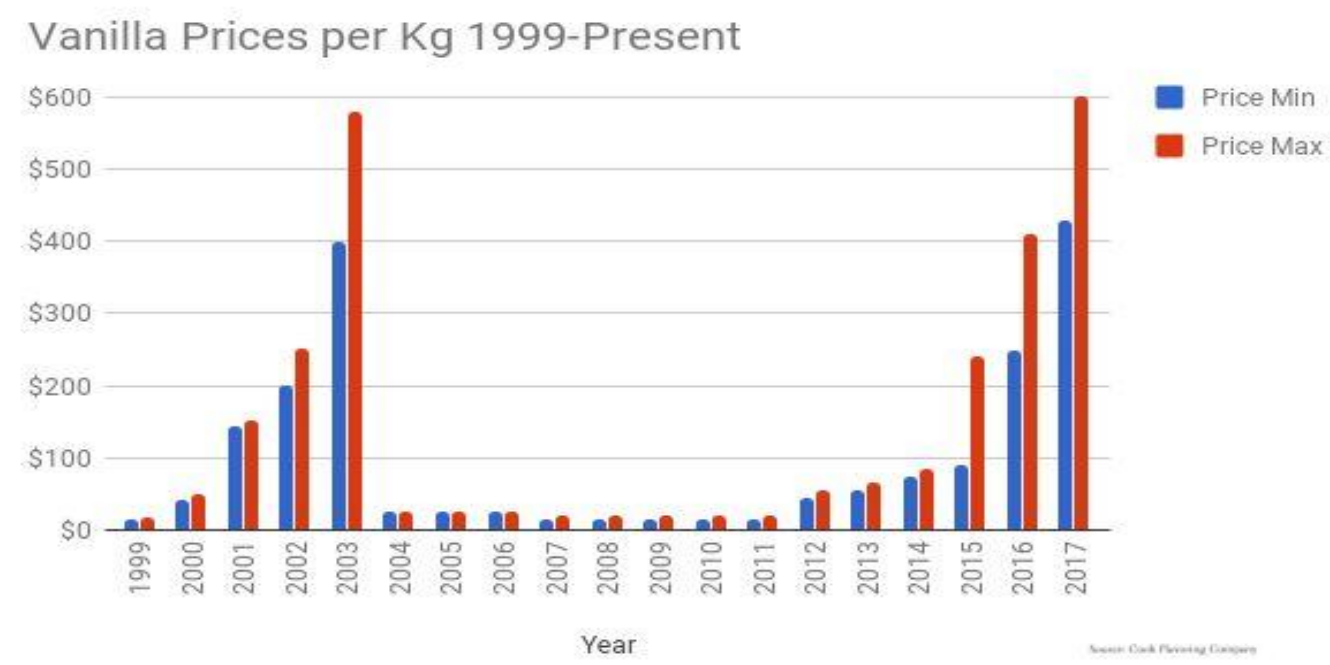

Gambar 3. Harga Vanili Pertahun

Vanili Indonesia merupakan Vanili terbaik Dunia dengan kadar Vanilin mencapai 2,6\%. Vanili asal madagaskar, saingan utama Indonesia hanya mengandung 
2,2\% Vanilin. Maklum, habitat terbaik vanili adalah zona di garis lintang 0-10". Madakaskar terletak di 20" lintang selatan. Sedangkan Indonesia terbentang dari 6", lintang utara sampai 11" lintang selatan. Untuk segmentasi penjualannya sudah ada yang bekerja sama 3 perusahaan besar untuk menerima pasokan hasil panen tanaman vanili yang dikelola oleh Rudi Ginting. Lama masa tanam idealnya adalah 10 hingga 11 bulan dari tanam pertama. Melihat dari potensi tanaman vanili ini akan sangat membantu pada perekonomian pesantren jika dilakukan budidaya di lingkungan pesantren. Sehingga pesantren "kecil" tidak lagi akan kesulitan pada sektor ekonomi dan pengembangan sarana dan prasarana serta pengembangan keilmuan dipesantren akan berjalan dengan sistematis tanpa mengalami kesulitan finansial.

Pada umumnya, lingkungan pondok pesantren memiliki beberapa ruas kosong yang tidak difungsikan seperti halaman Sekolah, halaman asrama dan ruang yang tidak digunakan sarana asrama. Tempat yang tidak produktif tersebut bisa dimanfaatkan untuk tempat tanam Vanili, disamping dapat menghasilkan profit juga menciptakan penghijauan halaman yang kurang produktif.

Tentu tidak menutup kemungkinan untuk pengembangan budidaya dengan jumlah yang banyak, bisa memanfaatkan lahan aset yang dimiliki pesantren. Pemanfaatan lahan pesantren nantinya bisa dijadikan pengembangan keahlian santri dalam hal pertanian. Manfaat budidaya vanili ini bisa memberikan keuntungan tersendiri bagi pesantren dengan jangka panjang. Pertama dari hasil budidaya ini, pesantren mampu berdiri sendiri tanpa ketergantungan pada eksternal pesantren, Kedua bisa dijadikan kebun atau tanaman percontohan untuk mengedukasi dalam pertanian sebagai bekal santri setelah selesai masa studi di pesantren.

Berbicara tentang tanamn Vanili tentu tidak akan lepas dari sejarahnya. Melihat tumbuhan vanili merupakan komoditi termahal kedua. Vanili ditemukan tahun 1570an oleh orang Indian dari suku Aztec yang hidup di Mexico dan mereka gunakan sebagai penyegar minuman. Namun vanili baru masuk Eropa sekitar tahun 1700-an dan dari situlah vanili menyebar ke berbagai negara hingga saat ini.

Tanaman vanili masuk ke Indonesia di bawa oleh bangsa Belanda sekitar tahun 1800an dengan tujuan awal untuk di tanam di Kebun Raya Bogor dalam rangka memperkaya koleksi tanaman yang di gagas oleh Prof Dr Reinwadt. Baru pada tahun 1860-an vanili mulai menyebar ke daerah Temanggung Jawa Tengah dan terus berkembang ke beberapa daerah seperti ke Sumatera Utara, Sumatera Selatan Sulawesi, Bali, NTB, NTT dan Papua. Pada periode 1960 sampai 1970 pulau Jawa adalah menjadi daerah terpesat dalam proses perkembangan tanaman vanili di Indonesia hingga bermunculan sentra-sentra vanili baru, sehingga vanili Indonesia pada saat itu lebih di kenal dengan sebutan Java Vanilla Beans.

Secara garis besar bila dikelompokan, inilah tahap perkembangan vanili di Indonesia adalah:

a. Tahap Perkembangan Pertama 1960-1970 di Jawa (Java Vanilla Bean) 


\section{b. Perkembangan Tahap Kedua}

1970-1982 di luar Jawa (Sumatera, Bali dan sekitarnya)

c. Perkembangan Tahap Ketiga

setelah 1982 Minahasa, Sulawesi dan kawasan timur Indonesia lainnya.

Jadi tidak mengherankan jika perkebunan vanili rakyat menyebar merata di seluruh Indonesia, sehingga pada era tahun 90-an Indonesia menjadi negara pengeksport vanili terbesar di dunia. Ketika memasuki era tahun 2000-an, industri makanan dan minuman mencoba beralih menggunakan vanili sintetis dan disaat bersamaan Indonesia memasuki era menjadi penguasa pasar vanili dunia. Sayangnya pasar yang besar, kepercayaan dunia yang tinggi di khianati dan di rusak oleh sebagian dari pelaku perdagangan vanili dari Indonesia tahun 2005. Di tahun tersebut vanili dari Indonesia mengalami tragedi, ditemukan adanya suntikan air raksa juga ditemukan kawat serta paku dalam polong vanili kering dari Indonesia untuk mensiasati berat bertambah sehingga vanili Indonesia ditolak di pasar dunia. Hingga saat ini, mengembalikan kejayaan vanili Indonesia masih sebatas mimpi dan vanili Indonesia di mata dunia sudah terpuruk.

Tanaman vanili merupakan tanaman tahunan yang tergolong dalam jenis tanaman anggrek dari suku (famili) Orchidaceae yang memiliki banyak macam spesies (lebih dari 1500 spesies). Vanilla planifolia adalah salah satu jenis tanaman perkebunan yang bernilai ekonomi tinggi dengan fluktuasi harga yang relatif stabil dibandingkan dengan tanaman perkebunan yang lain. Tanaman vanili memiliki Nilai cukup tinggi karena ekstrak buahnya bahan dasar pewangi pada bahan makanan dan minuman. Aroma yang khas dari hasil ekstrak buah vanili disebabkan oleh substansi vanilin.

Tanaman vanili di Indonesia di Indonesia banyak diminati oleh konsumen, baik di dalam negeri maupun dari luar negeri. Hal ini disebabkan karena kualitas vanili yang tumbuh Indonesia yang lebih unggul dibandingkan vanili di luar Negara Indonesia Seperti Mexico, Amerika Serikat, lebih-lebih Madagaskar yang juga terkenal sebagai penghasil vanili yang cukup Baik.

Pola pada sistem perakaran tanaman vanili tidak memiliki sistem akar tunggang, karena vanili termasuk ke dalam tanaman monokotil. Pada tiap ruas batang vanili, memiliki dua jenis akar, akar pertama berfungsi untuk melekat pada tanaman penegak yang disebut dengan sulur dahan, sedangkan akar ke-dua merupakan akar yang menggantung di udara yang berfungsi sebagai penyerap unsur hara dalam tanah jika akar tersebut telah menyentuh tanah. Batang tanaman vanili mampu tumbuh memanjang hingga mencapai 100 meter dan memiliki ruas-ruas yang panjang rata-rata sekitar $15 \mathrm{~cm}$. Tiap ruas akan menghasilkan cabang baru apabila dilakukan pemangkasan.

Adapun kegunaan dari vanili adalah tanaman yang menghasilkan pengharum alami jenis bubuk sebagai pengharum makanan. Nilai tambah terbesar dalam agroindustri vanili adalah proses pengolahan dan pengeringan sampai menjadi buah 
vanili kering. Sebab peningkatan harganya bisa mencapai enam setengah kali lipat dari harga vanili segar. Dengan asumsi harga vanili segar (kadar air 80\%) per $\mathrm{kg}$. $\mathrm{Rp}$ 200.000,- dan harga vanili kering (kadar air 35\%) Rp 3.000.000,- maka tiap kg. vanili segar akan menjadi sekitar 4,3 ons vanili kering. Biaya olah vanili segar sampai menjadi vanili kering tiap kilogramnya pasti hanya sebatas puluhan ribu rupiah. Hingga nilai tambah yang akan diperoleh para petani dari agroindustri pengeringan vanili, akan sangat tinggi.

Dalam kehidupan sehari-hari, aroma vanilin digunakan untuk pewangi makanan dan minuman, farmasi, kosmetika dan parfum. Industri makanan dan minuman, umumnya menggunakan ekstrak vanilin. Industri farmasi menggunakannya dalam bentuk tincture sementara untuk parfum berupa tincture dan absolute. Sebenarnya teknologi modern sudah berhasil membuat vanilin sintetis dari bahan baku eugenol (minyak daun cengkih), dengan cara mengubah jumlah dan bentuk rantai karbonnya. Namun konsumen dan kalangan industri tetap lebih menyukai aroma vanilin asli dari polong buah vanili. Itulah sebabnya apabila pasokan kurang, maka harga buah vanili kering akan melambung hingga mencapai puluhan juta rupiah per-kg.

Industri pangan vanili digunakan sebagai flavoring agent pada produk makanan dan minuman seperti pada es krim, minuman ringan, coklat, permen, puding, kue, dan minuman keras. Sedangkan dalam industri non pangan vanili banyak digunakan sebagai bahan untuk penambah wewangian (fragrance). Selain itu, vanili juga dapat dimanfaatkan sebagai zat antimikroba untuk mencegah jamur dan kapang pada puree buah, serta zat antioksidan pada makanan yang banyak mengandung komponen tak jenuh. Kombinasi vanillin dengan $500 \mathrm{ppm}$ asam askorbat pada $\mathrm{pH} 3$ mampu mencegah pertumbuhan mikroba alami dan kontaminan pure strawberry yang disimpan selama 60 hari pada suhu ruang. (Cerutti et al., 1997). Dengan begitu luasnya kegunaan vanili dan peningkatan ekspor vanili bean Indonesia, komoditi ini sebenarnya mempunyai prospek pengembangan yang sangat baik.

\section{Pesantren Dan Pengembangan Ekonomi Islam}

Saat ini, pondok pesantren merupakan alternatif pendidikan keagamaan Islam bagi masyarakat yang berkeinginan untuk menyekolahkan putra putrinya. Tidak berlebihan jika pesantren merupakan lembaga pendidikan selaian merupakan tempat belajar ilmu Agama Islam juga merupakan tempat pembentuk etika (akhlak) bagi siswa/i (santri) yang berkarakter ke- Indonesia-an. Fenomena dekadensi moral dalam dunia pendidikan akhir-akhir ini sangat memprihatinkan.

Sangat miris ketika dalam dunia pendidikan seorang siswa membunuh gurunya yang terjadi pada salahsatu daerah di Jawa Timur. Pergaulan bebas siswa/i yang semakin sulit dikontrol oleh guru dan orang tuanya. Pembunuhan yang dilakukan anak terhadap orang tuanya sendiri dan banyak fenomena anarkis yang dilakukan anak usia sekolah. Oleh karena itu, pesantren hadir dengan sistem serta aturan berdasarkan Agama. Pesantren hari ini nerupakan benteng konstruk moral paling ampuh untuk 
mendidik generasi muda yang jauh dari virus kenakalan remaja. Pesantren, sebagai perintis pendidikan Islam di Indonesia, sudah sewajarnya menjadi panutan bagi pendidikan Islam secara makro. Dengan ini, pesanteren harus melakukan rekonstruksi potensi strategis yang diperlukan bagi transformasi sosio-budaya Bangsa.

Sebagai lembaga pendidikan keagamaan dan lembaga kemasyarakatan, pesantren, pada saat ini juga diharapkan mampu berfungsi sebagai pelopor pembaharuan (agen of change). Dalam arti keberadaannya diharapkan mampu memberikan alternatif pemikiran dan tindakan. Didirikannya lembaga pendidikan pesantren adalah didasarkan atas panggilan kepada manusia untuk menjadi subyek yang selalu sadar dengan kemampuannya. Serta berpegang teguh pada nilai-nilai etika moralitas universal yang bersumber dari mata air Kibabullah dan sunnah Rasulullah (Zainal Arifin Thoha, 2003: 36).

1) Dinamika Pondok Pesantren : Selayang Pandang

Pesantren merupakan salah-satu model dari pendidikan berbasis masyarakat. Kebanyakan pesantren berdiri atas inisiatif masyarakat muslim yang tujuan utamanya adalah untuk mendidik generasi muda agar memahami dan mengamalkan jaran Islam dengan baik (Zubaedi: 2009). Pesantren identik dengan lembaga pendidikan kultural, beberapa simbol yang lekat dengan dunia pesantren adalah Kiai (sebagai pengasuh), santri (siswa/i), kitab kuning (Klasik). Gus Dur (Abdurrahman Wahid) memperkenalkan pesantren sebagai a place where santri (student) live. Selain itu, antroplog Amerika terkemuka Clifford Geertz menggambarkan pesantren sebagai komplek asrama siswa dikelilingi tembok yang berpusat pada suatu Masjid, ada seorang guru agama disebut Kiai, dan sejumlah siswa/i muda kebanyakan bujangan. Para santri yang mengaji al Qur'an, biasanya melakukan aktivitas mistik. (Manfred Ziemek: 1986) selanjutnya Geertz mengatakan bahwa Pesantren berarti tempat santri yang secara literal berarti manusia yang baik-baik. Dari ungkapan kedua tokoh tersebut menggambarkan bahwa pesantren merupakan pusat kajian keagamaan yang mempunyai ciri khas tersendiri dan berdampak pada hal yang positif.

Kelembagaan pada Pesantren berbeda dengan lembaga pendidikan lainnya. Mengacu pada argumentasi Abdurrahman Wahid bahwa pesantren mempunya setidaknya tiga elemen utama, yaitu: 1). Pola kepemimpinan pesantren yang mandiri dan tidak terkooptasi oleh Negara. 2). Kitab-kitab rujukan umum yang selalu digunakan diambil dari berbagai abad (dalam terminologi pesantren dikenal dengan kitab klasik atau kitab kuning); dan 3). Sistem nilai (value system) yang dianut (Abdurrahman Wahid: 1994).

Jika dilihat dari sejarahnya yang paling awal, pesantren didirikan dalam rangka mendidik, melatih, dan menanamkan nilai-nilai luhur (Akhlaqul Karimah) kepada santrinya, terutama kesederhanaan hudup, keikhlasan, kemandirian, asketisme (Zuhud), dan lain-lain. Ini semua merupakan nilai-nilai Islam, bahkan menjadi konsen semua ajaran Agama (Husen Muhammad, 2019: 18). 
Pendidikan pesantren mempunyai karakteristik yang melekat pada lembaga keagamaan tersebutsehingga lembaga pendidikan pesantren berbeda dengan pendidikan lainnya. Adapun karakter yang dimaksud adalah: Pertama adanya jalinan hubungan sangat akrab antara santri dengan Kiai, antara santri dengan santri lainnya. Hubungan antara santri dengan Kiainya diibadaratkan dengan hubungan Bapak dan anak, sementara hubungan santri dengan santri yang laian diibaratkan dengan hubungan antara saudara dalam sebuah keluarga besar yang mempunyai hubungan emosional yang tinggi. Proses kehidupan santri dalam pondok pesantren dilakukan secara teratur dengan pengawasan ketat serta dibimbing langsung oleh Kiai, bisa dikatakan pengawasan berlangsung selama 24 Jam. Dihampir semua pesantren, proses kehidupan berlangsung sejak jam 04.00 hingga jam 22.00 atau bahkan lebih. Diawali dengan sholat tahajjud kemudian sholat Subuh berjamaah, hingga pengajian kitabkitab klasik. Pagi sekolah Formal sore sekolah non formal hingga pengajian atau jam belajar malam. Kedua disamping sebagai pemilik dan pendiri pesantren, kiai juga menjadi pendidik dan orang tua para santri dengan otoritas yang tinggi. Ia sekaligus dilihat sebagai pribadi dengan penuh pesona. Kiai adalah pengambil kebijakan tertinggi dipesantren. Ditangannyalah arah pesantren ditentukan dan dibentuk. Dalam pandangan santri dan masyarakat kiai merupakan sosok kharismatik dan pribadi dengan wibawa.

Karisma kiai menurut mereka adalah karena dia memiliki otoritas keagamaan paripurna (par excellent). Seorang kiai memiliki pemahaman dan penguasaan yang luas dan mendalam terhadap teks-teks suci keagamaan al Qur'an dan Sunnah maupun khazanah intelektual islam yang ditulis oleh para ulama yang sering disebut dengan kitab kuning.

Pengaruh kekuasaan moral kiai memang jarang dapat diketahui orang-orang yang tidak pernah menjadi santri. Clifford Geertz mengatakan, "orang yang tidak pernah menjadi siswa dalam suatu pesantren, nyaris tidak dapat menyadari betapa besar kekuasaan moral seorang ulama atas massa rakyat." Mengacu pada pengertian santri secara umum dan mashur dibeberapa pondok pesantren. Makna santri mengandung nilai-nilai sosial keagamaan. Adapun makna santri secara etimologi sebagai berikut:

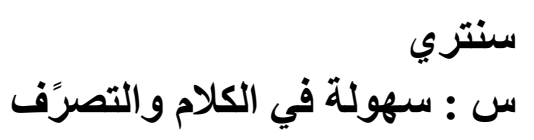

Lemah lembut perangai dan tingkah laku nya

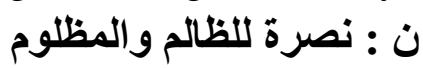

Menolong kepada mereka yang menzalimi dan dizalimi

ت : ترك الذ نوب الظا هرة والباطنة

Meninggalkan dosa dzahir dan batin ر : رحمة للعالمين

Menjadi rahmat bagi seluruh alam 


\section{ي : ب إعلى غيرهم}

Gemar menolong orang lain

2) Pesantren dan Pemberdayaan Bidang Ekonomi

Pesantren yang hakikatnya bercita-cita menciptakan kader ulama yang mendalami agama memiliki peran penting dalam pengembangan ekonomi masyarakat. Pesantren sudah saatnya peduli terhadap perkembangan ekonomi modern dan fakta perkembangan Ekonomi berbasis Islam. Tidak sedikit pesantren yang memiliki basis usaha sendiri, terutama koperasi pendok pesantren (Kopontren), Perusahaan (CV), perbengkelan, pertanian, kesehatan (Klinik). Juga ada lembaga keuangan pesantren, seperti Baitul Mal Wat Tamwil (BMT), Bazis, dan koperasi simpan pinjam. Ada juga kegiatan agrobisnis dan agroindustri di Pesantren. Jika dikelola dengan baik dapat memberi sumbangan berarti bagi perkembangan ekonomi secara makro. Apalagi pesantren memiliki sarana dan peluang bisnis yang lebih mapan, karena konsumennya sudah jelas. Setidaknya mereka yang nyantri dan masyarakat yang berdomisili di sekitar komplek peantren (Atho Mudzhar: 2017). Adanya pesantren dengan jumlah santri yang banyak mampu meningkatkan pertumbuhan ekonomi masyarakat secara signifikan.

Salah satu prinsip pemberdayaan adalah memahami terhadap kemampuan ekonomi yaitu, mampu memanfaatkan dan mengelola mekanisme produksi, distribusi, pertukangan dan jasa. Kemampuan dalam konteks ini berkaitan dengan kinerja perorangan yang merupakan wujud kompetensi individu tersebut dapat meningkat melalui proses pembelajaran langsung di lapangan, seperti kompetensi mengelola ekonomi. Kemampuan (pengetahuan dan keterampilan pengelola ekonomi) yang perlu ditingkatkan; sebagaimana diungkapkan oleh Damihartini dan Jahi adalah menyangkut aspek: (1) sumberdaya manusia; (2) kewirausahaan/enterpreneurship; (3) administrasi dan manajemen (organisasi); dan (4) teknis pertanian (Rimbawan, 2012: 1180-1199).

Pengetahuan dan skill merupakan salah-satu instrumen dalam mencapai kompetensi kerja. Pemberdayaan yang dilakukan oleh pesantren terhadap santrinya yaitu pemberdayaan melalui peningkatkan kompetensi dalam bidang ekonomi para santri agar nantinya para santri tersebut setelah membaur pada kehidupan masyarakatnya dapat menjadi figur baik dalam bidang ekonomi kreatif atau sebagai kader-kader pemberdaya ekonomi kerakyatan, di samping peran utamanya sebagai ustadz/ustadzah yang mempunyai kemampuan dalam bidang ilmu agama Islam. Usaha pemberdayaan masyarakat tersebut, bukan hanya tugas dan kewajiban pemerintah semata. Akan tetapi juga menjadi tanggung jawab bagi institusi atau organisasi lokal (pondok pesantren) yang ada di masyarakat. Hal ini dapat dijelaskan bahwa secara mendasar dan substantif, organisasi lokal memiliki kegiatan internal dan eksternal. Kegiatan internal berupa konsolidasi dan koordinasi ke dalam dengan membangun 
solidaritas dan komitmen. Sedang kegiatan eksternal berupa usahausaha pemberdayaan dan pelayanan kepada masyarakat.

Pondok pesantren pada kenyataannya adalah lembaga potensial untuk bergerak ke arah ekonomi berbasis rakyat (umat). Jika pondok pesantren tidak memberdayakan para santri di era yang akan datang, maka lembaga-lembaga ekonomi mikro lain yang justru akan lari dan menggesernya untuk mengarah pada kemajuan. Oleh karena itu, diperlukan adanya analisis yang cermat dalam melakukan penguatan kelembagaan ekonomi pada lembaga pendidikan pesantren, agar tidak salah melangkah. Sebenarnya, sasaran akhir dari pemberdayaan ekonomi pondok pesantren adalah kemandirian dari pesantren.

Dalam pengembangan masyarakat, pesantren melakukan empat hal. Pertama, melakukan upaya-upaya pembebasan dan penyadaran masyarakat dari kondisi kehidupan sosial yang menghimpit seperti kemiskinan. Kedua, menggerakkan partisipasi dan etos swadaya masyarakat dengan memposisikan pesantren sebagai fasilitator. Masyarakat didorong untuk dapat mengidentifikasi permasalahan yang dihadapi dan bagaimana mengurai solusislusinya. Ketiga, pesantren mendidik dan menciptakan pengetahuan. Keempat, pesantren mempelopori cara-cara memecahkan permasalahan kehidupan sosial kemasyarakatan.

3) Ekonomi Islam sebagai landasan Ekonomi Pesantren

Konsepsi Ekonomi Islam merupakan sebuah Mindset dan konstruksi yang disandarkan kepada visi atau penciptaan semesta. Ekonomi Islam dipandang bukan sekedar seperangkat teori yang didasarkan kepada asumsi-asumsi, melainkan jalan hidup (The Way of life) dan selalu berkaitan dengan aktualitas. Sejalan dengan hal tersebut, Umer Chapra menegaskan bahwasanya ekonomi Islam merupakan formulasi yang didasarkan atas pandangan Islam tentang hidup dan kehidupan yang mencakup segala hal yang diperlukan untuk merealisasikan keberuntungan (Falah) dan kehidupan yang baik (Hayya Thayyibah) dalam bingkai aturan syariah yang menyangkut pemeliharaan keyakinan (Faith), jiwa atau kehidupan, akal pikiran, keturunan, harta kekayaan (Havis Aravik: 2017).

Selanjutnya, ekonomi Islam adalah sebuah ilmu pengetauan yang membantu upaya realisasi kebahagiaan manusia melalui alokasi dan distribusi sumber daya yang terbatas yang berada dalam koridor dan mengacu ajaran Islam tanpa memberikan kebebasan individu atau tanpa perilaku Makro ekonomi yang berkelanjutan dan tanpa ketikseimbangan lingkungan. Definisi tersebut mengisyaratkan bahwa ekonomi Islam merupakan suatu cabang ilmu pengetahuan untuk membantu merealisasikan kesejahteraan manusia melalui alokasi dan distribusi sumber-sumber daya langka yang seirama dengan tujuan syariat Islam atau Maqasid al-Syariah tanpa mengekang kebebasan perorangan, menciptakan ketidakseimbangan makro ekonomi dan ekologi, atau melemahkan solidaritas keluarga dan sosial serta jaringan moral masyarakat. Oleh sebab itu, tujuan ekonomi Islam adalah mewujudkan tingkat pertumbuhan ekonomi jangka panjang dan memaksimalkan kesejahteraan manusia (Falah). 
Kesejahteraan yang dimaksud tidak hanya berkaitan dengan terpenuhinya materi semata, tetapi juga terpenuhinya kebutuhan spiritual dalam kata lain kebutuhan individu masyarakat dengan tidak mengabaikan keseimbangan makroekonomi (kepentingan sosial), kepentingan ekologi dan tetap memperhatikan nilai-nilai keluarga dan norma.

Menurut al-Sadr ekonomi Islam bukanlah sebuah disiplin ilmu, melainkan sebuah mazhab atau doktrin yang direkomendasikan Islam, dengan demikian, ekonomi Islam adalah doktrin karena ia membicarakan semua aturan dasar dalam kehidupan ekonomi yang dihubungkan dengan ideologinya mengenai keadilan (sosial). Oleh sebab itu, kehadiran Islam, khususnya ajaran tentang ekonomi, bukan hendak menemukan fenomena tentang ekonomi ditengah masyarakat, akan tetapi ingin menerapkan ajaran Islam di bidang ekonomi.

Al-Sadr mengajak setiap muslim untuk membedakan antara ekonomi sebagai sistem dan ekonomi sebagai ilmu. Sebagai sistem, ekonomi mengacu pada cara suatu masyarakat mengatur kehidupan dalam hal ekonominya. Adapun sebagai sebuah ilmu, ekonomi mengacu kepada upaya memahami berbagai peristiwa dan gejala ekonomi berdasarkan kerangka teori tertentu yang menjelaskan korelasi antara peristiwa dan gejala itu dengan berbagai faktor yang mengitarinya. Karena sistem ekonomi Islam merupakan bagian dari sistem ekonomi Islam secara keseluruhan dan harus dipelajari sebagai interdisipliner, bersama dengan seluruh anggota masyarakat yang merupakan agen sistem Islam. Maka, seseorang harus mempelajari pandangan dunia Islam terlebih dahulu, jika ingin mendapatkan hasil yang memuaskan dalam menganalisis sistem ekonomi Islam. Karena konsep dasar dalam ekonomi Islam bersifat Tsubut dan dari sini dihasilkan aturan-aturan (teori) yang bersifat fleksibel sesuai dengan tuntutan zaman. Diantara doktrin ekonomi tersebut adalah kepemilikan multi jenis, kebebasan dalam aktivitas ekonomi dan nilai keadilan, karena ekonomi Islam adalah doktrin yang berisi prinsip dasar, maka Islam memberikan ruang kosong yang cukup luas untuk diisi oleh negara sebgai wali al-amr.

Ekonomi Islam dibangun berdasarkan al-Qur'an dan Sunnah dan tidak ada korelsinya dengan teori-teori ekonomi dunia yang konvensional. Jadi, dapat dipahami bahwa tidak ada kompromi dan korelasi antara sistem ekonomi Islam dan sistem ekonomi konvensional karena secara hakikat dan filosofis, keduanya sangat kontradiktif.

\section{Metode Dan Teknik Penggalian Data Penelitian}

Metode pada pemberdayaan ekonomi Pesantren dengan budidaya Vanili dengan sistem agrikultur, akan dilakukan dengan beberapa tahap. Pertama, melakukan survei dan pembinaan awal di beberapa Pesantren terkait potensi tanaman Vanili serta kegunaan dan pemasarannya. Kedua, menyediakan tunas vanili berbentuk polybag yang siap tanam dan didistribusikan ke Pesantren. Ketiga melakukan pendampingan dan pelatihan dari awal terkait dengan penanaman, perawatan hingga panen dan 
membantu memasarkan yang telah kami sediakan. Karena kemitraan pemberdayaan ini telah bekerja sama dengan beberapa pengusaha di beberapa Negara yang sangat membutuhkan Vanili.

Adapun penggalian data yang kami lakukan untuk merancang pemberdayaan ini secara profesional dan proporsional adalah melakukan pra-riset terlebih dahulu. Prariset ini dilakukan dengan dua langkah, pertama klasifikasi masalah yang berkaitan dengan masalah perekonomian pesantren, kedua adalah menjalin kemitraan dengan pakar pertanian dalam hal ini urgensitas tanaman vanili dan kegunaannya sehingga meunculkan kansep natural setting pada pelaku budidaya. Hal ini ditegaskan oleh Capra (2000) pada uraian elemen strategis Islam dalam pembangunan ekonomi keummatan. Mengatakan bahwa adanya Restrukturisasi sosio ekonomi menciptakan situasi yang kondusif bagi penerapan nilai-nilai ekonomi Islam (Nur Riyanto, 2017: 130). Kemudian melakukan analisis peluang pasar pada penjualan hasil pemberdayaan. Dan kami juga akan melakukan pemetaan skala prioritas untuk pesantren-pesantren dan menjadikannya sebagai pesantren binaan dalam hal pemberdayaan sektor ekonomi pengembangan pesantren.

Berikut dokumentasi kebun percontohan yang ada di kabupaten Bondowoso
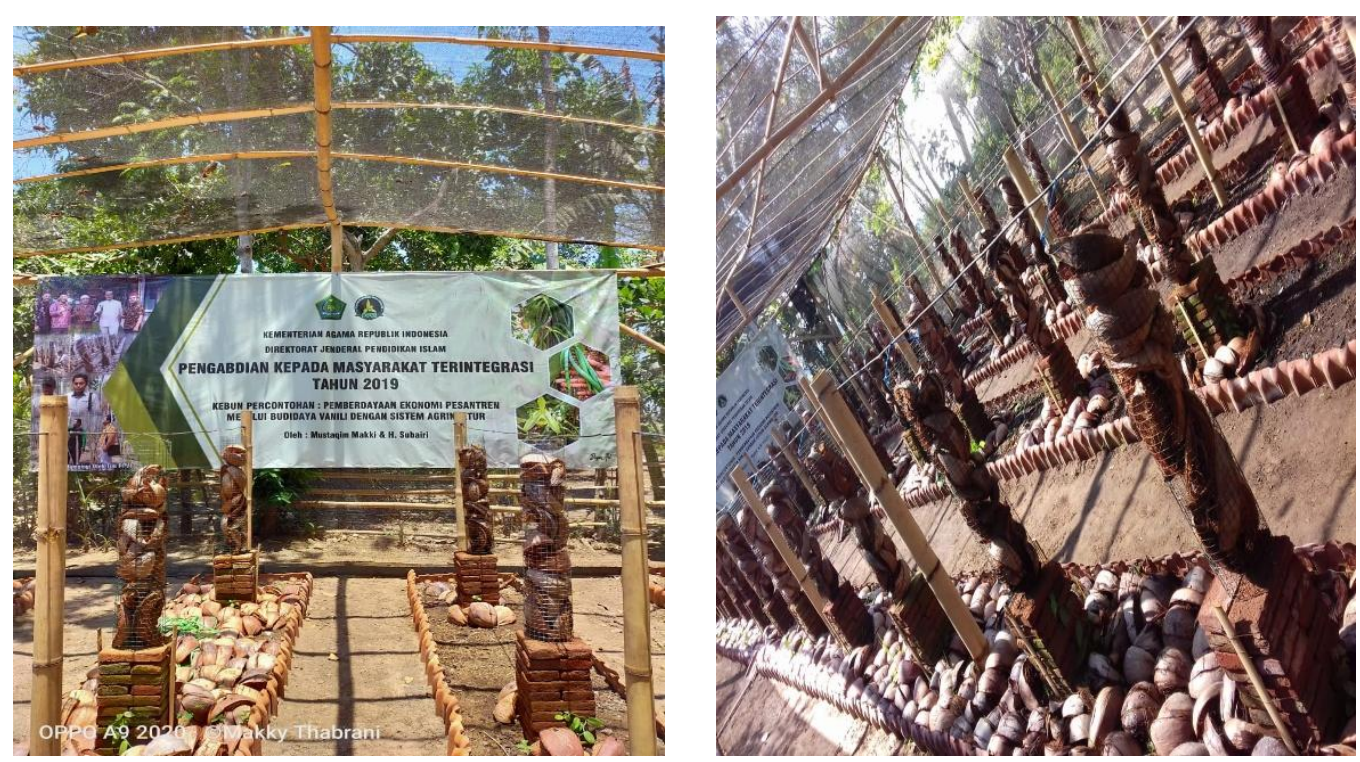

Gambar 4. Kebun Percontohan di Kabupaten Bondowoso 


\section{Hasil Penelitian}

\section{Kerangka Pemberdayaan Pada Budidaya Vanili Untuk Pengembangan Ekonomi Pesantren}

Pemberdayaan dalam Kamus Besar Bahasa Indonesia, pemberdayaan berakar dari kata daya, bermakna: a) kemampuan melakukan sesuatu atau kemampuan bertindak; b) kekuatan, tenaga (yang menyebabkan sesuatu bergerak dan sebagainya); c) muslihat, empat, akal, ikhtiar, upaya. Pemberdayaan itu sendiri bermakna proses, cara, perbuatan memberdayakan.

Adapun makna pemberdayaan menurut para ahli memiliki beragam pengertian dan arti, diantaranya menurut:

a) C. Swift dan G. Levin : Pemberdayaan merupakan suatu usaha pengalokasian kembali kekuasaan melalui perubahan structural.

b) J. Ife: pemberdayaan bertujuan untuk meningkatkan kekuasaan orang-orang lemah atau kurang beruntung.

c) J. Rappaport: Pemberdayaan merupakan suatu cara dengan memberdayakan orang, organisasi, komunitas, diarahkan supaya mampu menguasai (atau berkuasa atas) kehidupannya.

d) M. Payne: pemberdayaan bertujuan untuk membantu orang memperoleh daya (kekuasaan) dalam mengambil keputusan dan tindakan terhadap hidup mereka dengan mengurangi efek hambatan sosial dan pribadi. Hal ini dilakukan melalui peningkatan kemampuan dan rasa percaya diri dengan menggunakan daya (kekuasaan) dan dengan mentransfer daya dari lingkungan kepada orang.

e) R.J Parson: pemberdayaan menunjuk suatu proses dengan menjadi cukup kuat untuk berpartisipasi dalam berbagai pengontrolan atas, dan mempengaruhi terhadap kejadian-kejadian dan lembaga yang mempengaruhi kehidupannya.

Dari ulasan di atas berdasarkan kamus dan pendapat para ahli tersebut, maka penberdayaan bisa disimpulkan sebagai suatu proses transfer power (daya atau kuasa) pada yang lemah (powerlesness) atau mengembalikan power kepada pemiliknya semuala, melalui proses tersebut, orang, kelompok atau masyarakat mampu mengelola kebutuhan dan permasalahannya sendiri.

Adapun jenis pemberdayaan terbagi menjadi dua proses, pertama proses transfer, kedua proses pengembalian. Proses pertama terkait dengan proses penambahan daya yang dimiliki sebelumnya lemah. Proses kedua adalah proses ambil alih pada orang, kelompok, yang awalnya memiliki daya atau kuasa kemudian diambilalih oleh pihak ketiga. 


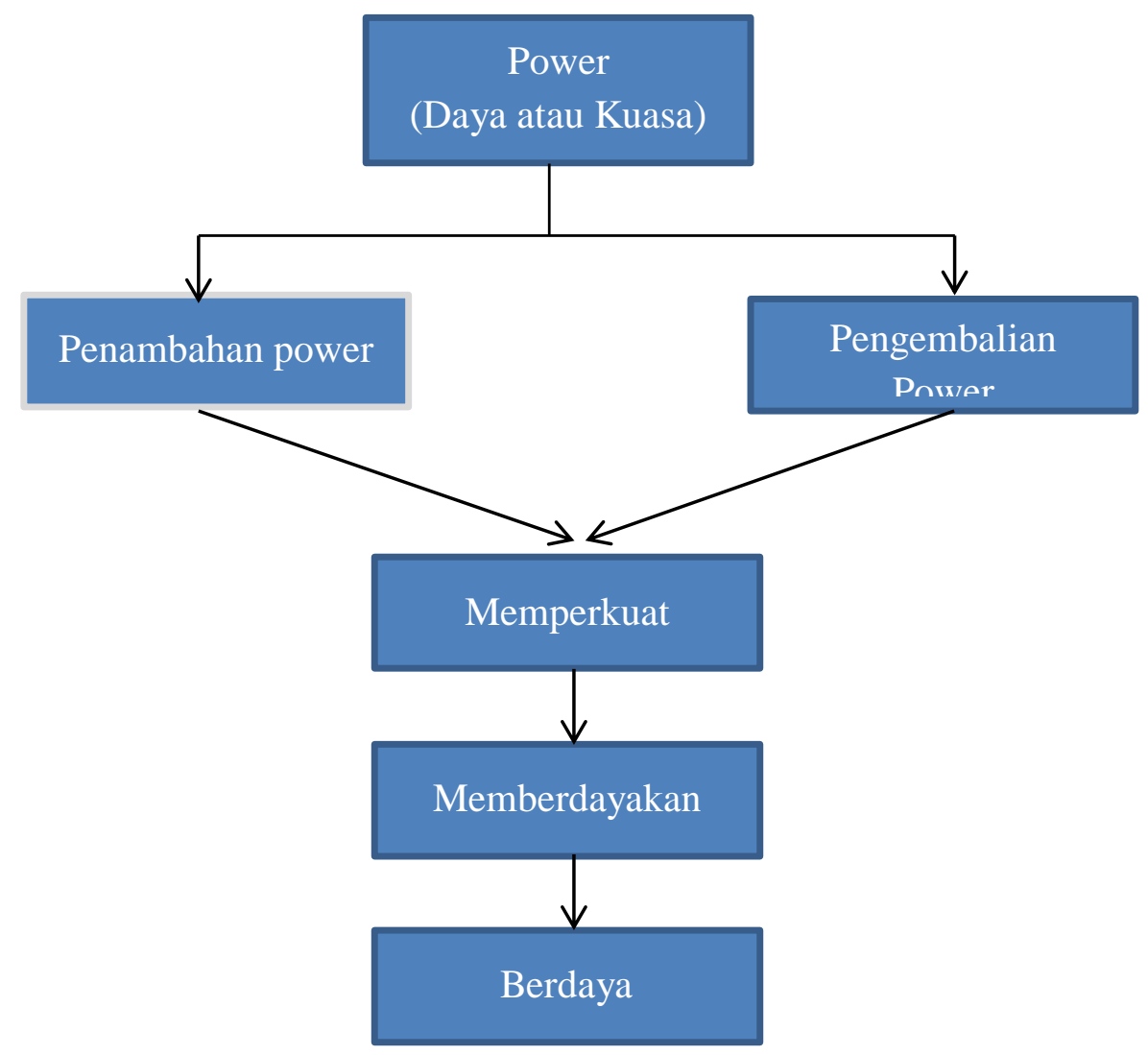

Gambar 5. Proses Peningkatan Ekonomi Pesantren

Aspek pemberdayaan orang, kelompok masyarakat dituntun menjadi kuat untuk berpartisipasi dan memiliki kreativitas. Melalui pemberdayaan masyarakat, aspek partisipasi dan kreativitas dikelola sedemikian rupa. Sehingga dipandang perlu untuk melakukan pendampingan agar daya (kuasa) yang dimiliki oleh orang ataupun kelompok masyarakat bisa dioptimalkan.

Setelah melakukan analisa anggran dan sistem penanaman, yang awalnya akan dilakukan dibeberapa pesantren yang ada di Bondowoso. Maka ditetapkan penanaman dalam satu titik dikecamatan cermee desa grujugan. Konsep penanaman ini adalah Kebun percontohan. Dimana bibit yang dihasilkan akan didistribusikan ke beberapa Pesantren secara gratis dan didampingi oleh TIM PPVI. 


\section{E. Kesimpulan}

Pemberdayaan pada ekonomi pesantren melalui budidaya vanili dengan sistem agrikultur merupakan salah satu alternatif pengembangan perekonomian pesantren. Kita kenal selama ini instrumen pendukung ekonomi pesantren adalah adanya kopontren, Baitul Mal Wattamwil, simpan pinjam berbasis koerasi. Dalam bidang pertanian pada umumnya hanya ditanami tanaman-tanaman konvensional seperti jagung dan padi, hasilnya tidak begitu signifikan.

Adanya pemberdayaan ini memberikan terobosan baru bagi lembaga pesantren untuk pengembangan ekonomi sehingga sistem dalam pesantren tidak lagi terganggu dengan faktor lemahnya ekonomi. Dengan adanya budidaya vanili, pesantren tidak hanya bisa menggembangkan perekonomian akan tetapi juga bisa mengembangkan SDM para santri dengan memberikan beasiswa untuk melanjutkan pendidikannya. Dan integritas pesantren lebih tercitra baik karena tidak lagi ketergantungan pada pihak ekternal, baik alumni maupun donatur.

\section{Daftar Pustaka}

Ahmad Warson Munawwir, (1997). Kamus Arab Indonesia al-Munawwir.Surabaya: Pustaka Progressif,

Azzumardi Azra. (1997). Jaringan Ulama. Bandung: Mizan.

Aravik Havis. (2017). Sejarah Pemikiran Eonomi Islam Kontemporer. Depok:Pustaka Kencana

Asy'ary Musa. (2017). Filsafat Ekonomi Islam.Jogjakarta: Lesfi

Al Arif Nur Rianto. (2016). Pengantar Ekonomi Syariah, Teori dan Praktek. Bandung: Pustaka Setia

Damsar. (2017). Pengantar Sosiologi Pedesaan, Depok:Pustaka Kencana

Herman DM. (2013) Sejarah Pesantren di Indonesia, Moraref, Jurnal al Ta'dib. Vol 6 No,2. Juli-Desember 2013

Moh Nadzir. (2015). Membangun Pemberdayaan Ekonomi Pesantren, Moraref Jurnal, Vol VI/ Edisi I/ Mei 2015

Nadzir, Mohammad. "Membangun Pemberdayaan Ekonomi Di Pesantren." Economica: Jurnal Ekonomi Islam 6.1 (2015): 37-56.

Pangkalan Data Pondok Pesantren. Ditpdpontren.kemenag.go.id

Rimbawan, Y. (2012). Pesantren dan Ekonomi: Kajian Pemberdayaan Ekonomi Pesantren Darul Falah Bendo Mungal Krian Sidoarjo Jawa Timur.

Zainal Arifin Thoha. (2003). Runtuhnya Singgasana Kiai "NU” Pesantren dan Kekuasaan: Pencarian Tak Kunjung Usai, Yogyakarta: Kutub 